\title{
INFLUENCE OF HOST SEX AND AGE ON INFRACOMMUNITIES OF METAZOAN PARASITES of Prochilodus lineatus (Valenciennes, 1836) (Prochilodontidae) of the Upper Paraná River floodplain, Brazil
}

\author{
LIZAMA M. DE LOS A.P.*, TAKEMOTO R.M.***** \& PAVANELLI G.C.****
}

\section{Summary:}

149 specimens of Prochilodus lineatus were collected on the upper Paraná River floodplain. Of these, 121 (82.1\%) were parasitized. 33 species of metazoan parasites were recorded. Rhinonastes pseudocapsaloideum was classified as secondary, while all other species were classified as satellites. Ergasilus sp. and Tereancistrum curimba were positively associated and their abundances were positively correlated. Saccocoelioides magnorchis and S. nanii were positively associated and their abundances were positively correlated. The mean diversity in the infracommunities of $P$. lineatus was $H=0.6875 \pm 0.4398$. Host standard length was not correlated with parasite diversity (rs $=0.1726 ; p=0.0533$ ). The abundances of $T$. curimba and Kritskyia boegeri, and S. magnorchis and S. nanii were significantly correlated with host length. Correlation between fish age and parasite prevalence was not significant. The abundances of Amplexibranchius sp., K. boegeri and S. magnorchis were significantly different among host age classes. For Amplexibranchius sp., the three-year old age class had more parasites. For K. boegeri, the intermediate age classes had the most numerous parasites. Only Tereancistrum curimba showed significant difference in the prevalence between the sexes, with females being more parasitized.

KEY WORDS : metazoan parasite, Prochilodus lineatus, upper Paraná River, floodplain, Brazil

\section{INTRODUCTION}

T The curimba Prochilodus lineatus (Valenciennes, 1836) is one of the most abundant species on the upper Paraná River floodplain and of commercial importance. Curimba are large-sized and carry out extensive migrations to feed and reproduce. Iliophagous, its diet is composed primarily of detritus and sediment (Fugi et al., 1996; Agostinho et al., 1997).

\footnotetext{
* State University of Maringá, Postgraduate Course in Ecology of Continental Aquatic Environments (PEA), Bloco G-90, Av. Colombo, 5790, 87020-900, Maringá, PR, Brazil.

** State University of Maringá, Nupélia (Nucleus of Research in Limnology, Ichthyology and Aquaculture), Bloco G-90, Av. Colombo, 5790, 87020-900, Maringá, PR, Brazil.

Correspondence: Ricardo M. Takemoto.

Tel.: +55 44 3261-4642 - Fax: +55 44 3263-1424.

E-mail: takemotorm@nupelia.uem.br
}

Résumé : INFLUENCE DU SEXE ET DE L'ÂGE DE L'HÔTE SUR LES infracommunautés de mÉtazoaires ParastTes De PROCHILODUS linEatus (VAlenciennes, 1836) (Prochilodontidae) De LA Plaine

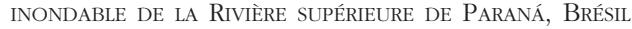

149 spécimens de Prochilodus lineatus ont été recueillis dans la plaine inondable de la Rivière supérieure de Paraná. 121 (82, $1 \%$ ) étaient parasités. 33 espèces de métazoaires parasites ont été retrouvées. Rhinonastes pseudocapsaloideum a été classifié comme étant secondaire, et toutes les autres espèces comme satellites. Ergasilus sp. et Tereancistrum curimba ont été retrouvés associés et leurs abondances corrélées positivement. Il en est de même pour Saccocoelioides magnorchis et $\mathrm{S}$. nanii. La diversité moyenne dans les infracommunautés de $\mathrm{P}$. lineatus était $H=0,6875 \pm 0,4398$. La taille de l'hôte n'était pas corrélée à la diversité parasitaire ( $r s=0,1726 ; p=0,0533)$. Les abondances de T. curimba et Kritskyia boegeri, et $\mathrm{S}$. magnorchis et S. nanii étaient significativement corrélées à la longueur de l'hôte. La corrélation entre l'âge du poisson et la prévalence du parasite n'était pas significative. Les abondances de Amplexibranchius sp., K. boegeri et S. magnorchis étaient significativement différentes selon les classes d'âge de l'hôte. Pour Amplexibranchius sp., la classe d'âge de trois ans était la plus parasitée. Pour K. boegeri, les classes d'âge intermédiaires étaient les plus parasitées. Seul Tereancistrum curimba a montré une différence significative de prévalence selon le sexe, les femelles étant les plus parasitées.

MOTS CLÉS : métazoaires parasites, Prochilodus lineatus, plaine inondable, Rivière supérieure de Paraná, Brésil.

Studies about this species have broached prominent aspects of population structure and biology (e.g. Terraes et al., 1999; Lizama, 2000; Ranzani Paiva et al., 2000). Important information about the parasitic fauna of this host has recently been reported. Takemoto et al. (2002) described a new species of monogenean parasite of the urinary bladder, Domingues et al. (2002) described a new species of monogenean parasite of the nasal cavity and Lizama et al. (2004) described two species of gill monogeneans. As regards parasite ecology, Martins et al. (2001), referred only to seasonal variation in parasitism levels of the acanthocephalan Neoechinorbynchus curemai.

The object of this study was to evaluate the relationships between the host Prochilodus lineatus and the metazoan parasite fauna, including the influence of host sex and length/age on parasite infrapopulations. 


\section{MATERIALS AND METHODS}

49 specimens of Prochilodus lineatus were collected between February 2000 and June 2001 on the upper Paraná River floodplain in the "Ilhas e Várzea

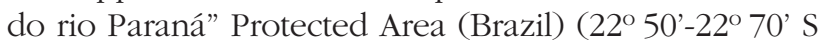
and $\left.53^{\circ} 15^{\prime}-53^{\circ} 40^{\prime} \mathrm{W}\right)$. The total weight, standard length and sex of each fish were recorded. The internal organs and the visceral cavity were analyzed under a stereomicroscope. The collected parasites were treated according to Eiras et al. (2000) and identified based on Thatcher (1978, 1979, 1991 and 1993), Thatcher \& Boeger (1984a, b), Thatcher \& Varella (1981), Moravec (1998), Takemoto et al. (2002) and Lizama et al. (2004). The age of each specimen was established according to the growth parameters estimated in Lizama (2000) and applied to obtain the mean length of each age class. Statistical tests were applied to species that had presented prevalence higher than $10 \%$ (Bush et al., 1990). Significant difference was assumed when $p \leq 0.05$. The dispersion index and the Green index were used to verify dispersion patterns of the parasite species. The dispersion index was tested using the statistic $d$ (Ludwig \& Reynolds, 1988). The diversity of each metazoan parasite infracommunity was calculated using the Brillouin index (H). The possible correlation between diversity and host standard length was determined using Spearman's rank correlation (rs). The value of importance (Hanski, 1982; Bush \& Holmes, 1986; Esch et al., 1990) was used to verify the importance of each species in the metazoan parasite community. Species considered central were present in more than $66.66 \%$ of the analyzed fish; secondary $=$ presence between $33.33 \%$ and $66.66 \%$; satellites $=$ less than $33.33 \%$. The terminology used throughout this study is from Bush et al. (1997).

\section{RESULTS}

F ish standard length was $4.2-44.0 \mathrm{~cm}$ (mean = $25.6 \pm 6.9$ ) and weight was $2.1-2,602.2 \mathrm{~g}$ (mean $=$ $566.3 \pm 403.4)$.

Of the 149 analyzed fish, 121 (82.1\%) were parasitized by one or more species of metazoan parasite. 33 metazoan parasite species were recorded. The digeneans was the group with the largest number of specimens (Table I).

\section{ECOLOGICAL ASPECTS OF THE METAZOAN PARASITE INFRACOMMUNITY}

A total of 2,662 parasite specimens belonging to 33 species were collected. Endoparasites accounted for $63.35 \%$ of the metazoan parasites. The digeneans Saccocoelioides magnorchis and $S$. nanii were the most abundant and the ectoparasites Rhinonastes pseudocapsaloideum and Kritskyia boegeri were the most prevalent among all parasite species. According to the value of importance, only Rhinonastes pseudocapsaloideum was considered secondary, while the other species were considered satellites. No species were classified as central (Table I). The metazoan parasite population of $P$. lineatus was overdispersed and there was low aggregation for all species. The copepod Amplexibranchius sp. presented the highest aggregation value (Table I).

No pair of species showed association among the ectoparasites of the nasal cavity. The abundance values of gill ectoparasites Ergasilus sp. and Tereancistrum curimba were positively correlated, showing positive association (Chi-square with the Yates correction, $\chi^{2}=3.667$; Spearman's rank correlation, $r s=0.215 ; \mathrm{p}=0.0083$ ) Abundances of Saccocoelioides magnorchis and S. nanii were positively associated $\left(\chi^{2}=13.359\right.$; rs $=0.353$; $\mathrm{p}<0.001)$.

The metazoan parasite community of $P$. lineatus presented mean diversity of $\mathrm{H}=0.6875 \pm 0.4398$. Host standard length was not correlated with diversity ( $\mathrm{rs}=$ 0.1726; $\mathrm{p}=0.0533$ ). Parasite community richness showed a predominance of four species per host, followed by two and five species.

\section{STANDARD LENGTH/AGE}

Among the 11 most prevalent species (> $10 \%$ ) of parasites, the monogeneans T. curimba ( $\mathrm{rs}=0.253 ; \mathrm{p}=$ 0.001 ) and $K$. boegeri ( $r s=0.223 ; \mathrm{p}=0.006$ ), and the digeneans S. magnorchis ( $\mathrm{rs}=0.190 ; \mathrm{p}=0.020$ ) and S. nanii ( $\mathrm{rs}=0.252 ; \mathrm{p}=0.019$ ) presented significant correlations between host standard length and abundance. No metazoan species presented correlation between prevalence and fish age.

Fish up to one year old are not parasitized; after this period, the frequency of parasitism increases to $79.0 \%$ (Fig. 1). There are no differences between the mean

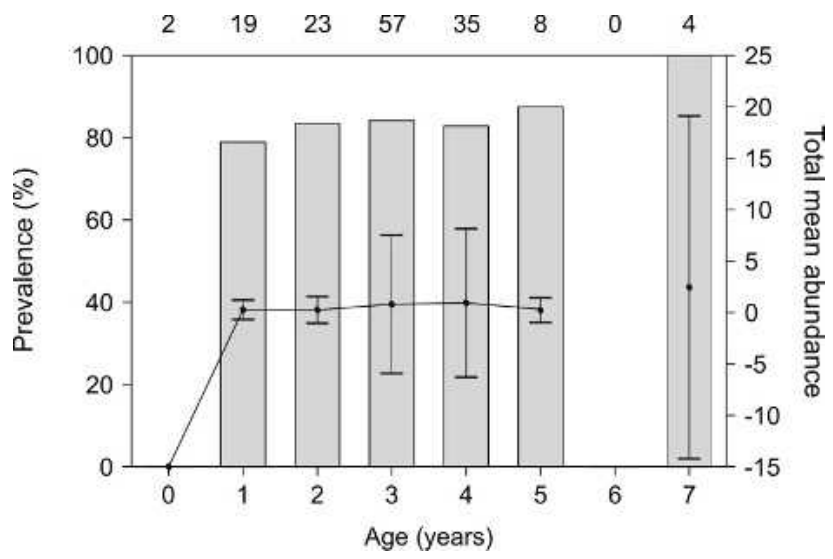

Fig. 1. - Frequency of parasitism for each age class of Prochilodus lineatus, captured on the upper Paraná River floodplain from February 2000 to June 2001 (Numbers on the top of the graph refer to the number of examined fishes). 


\begin{tabular}{|c|c|c|c|c|c|c|c|c|}
\hline Parasite & $\mathbf{P}$ & $\mathbf{M A} \pm \mathbf{S D}$ & AI & Classif. & DI & $d$ & GI & Site of infection/infestation \\
\hline \multicolumn{9}{|l|}{ Monogenea } \\
\hline Rhinonastes pseudocapsaloideum & 43.62 & $1.31 \pm 2.35$ & $1-15$ & Se & 4.303 & $18.390^{*}$ & 0.018 & Nasal cavity \\
\hline Kritskyia boegeri & 28.85 & $1.55 \pm 3.53$ & $1-17$ & Sa & 8.037 & $31.583^{*}$ & 0.030 & Urinary bladder \\
\hline Tereancistrum curimba & 22.80 & $0.75 \pm 2.45$ & $1-20$ & Sa & 7.980 & $31.427^{*}$ & 0.063 & Gills \\
\hline Tereancistrum toksonum & 5.30 & $0.23 \pm 1.29$ & $1-13$ & Sa & - & - & - & Gills \\
\hline Tereancistrum sp. & 0.67 & $0.01 \pm 0.08$ & 1 & Sa & - & - & - & Gills \\
\hline Gyrodactylus sp. 1 & 3.35 & $0.05 \pm 0.29$ & $1-3$ & Sa & - & - & - & Nasal cavity \\
\hline Gyrodactylus sp. 2 & 3.35 & $0.05 \pm 0.32$ & $1-3$ & Sa & - & - & - & Gills \\
\hline Anacanthoroides sp. & 2.01 & $0.05 \pm 0.41$ & $1-4$ & Sa & - & - & - & Gills \\
\hline Ancyrocephalinae & 6.04 & $0.23 \pm 1.16$ & $1-9$ & Sa & - & - & - & Gills \\
\hline \multicolumn{9}{|l|}{ Digenea } \\
\hline Saccocoelioides magnorchis & 26.84 & $3.63 \pm 11.45$ & $1-114$ & Sa & 38.568 & $88.758^{*}$ & 0.078 & Intestine, stomach, pyloric cecae \\
\hline Saccocoelioides nanii & 26.84 & $8.97 \pm 30.35$ & $1-200$ & $\mathrm{Sa}$ & 102.643 & $157.130 *$ & 0.076 & Intestine, stomach, pyloric cecae \\
\hline Saccocoelioides leporinodus & 2.68 & $0.07 \pm 0.47$ & $1-5$ & Sa & - & - & - & Intestine \\
\hline Saccocoelioides saccodontis & 0.67 & $0.01 \pm 0.16$ & 2 & Sa & - & - & - & Intestine \\
\hline Saccocoelioides sp. & 0.67 & $0.04 \pm 0.49$ & 6 & Sa & - & - & - & Intestine \\
\hline Unicoelium prochilodorum & 5.37 & $0.20 \pm 1.66$ & $1-2$ & Sa & - & - & - & Intestine \\
\hline Megacoelium sp. & 5.37 & $0.12 \pm 0.64$ & $1-6$ & Sa & - & - & - & Intestine, stomach \\
\hline Tylodelphis sp. (metacercariae) & 10.74 & $0.17 \pm 0.80$ & $1-9$ & Sa & 3.818 & 16.441* & 0.117 & Gills \\
\hline Colocladorchis sp. & 8.05 & $0.29 \pm 2.39$ & $1-29$ & Sa & - & - & - & Intestine \\
\hline Sphincterodiplostomum sp. (metac.) & 0.67 & $0.01 \pm 0.08$ & 1 & Sa & - & - & - & Gills \\
\hline Lecitobothrioides sp. & 0.67 & $0.01 \pm 0.16$ & 2 & Sa & - & - & - & Intestine \\
\hline Digenea 1 (metacercariae) & 2.01 & $0,05 \pm 0.43$ & $1-6$ & Sa & - & - & - & Mesentery \\
\hline Digenea 2 (metacercariae) & 0.67 & $0.02 \pm 0.25$ & 3 & Sa & - & - & - & Heart \\
\hline \multicolumn{9}{|l|}{ Cestoda } \\
\hline Proteocephalidea (plerocercoid) & 5.36 & $0.25 \pm 1.28$ & $1-10$ & Sa & - & - & - & Mesentery \\
\hline Valipora campylancristrota & 5.37 & $0.09 \pm 0.53$ & $1-6$ & Sa & - & - & - & Gall bladder \\
\hline \multicolumn{9}{|l|}{ Nematoda } \\
\hline Raphidascaris sp. & 2.01 & $0.02 \pm 0.14$ & 1 & Sa & - & - & - & Intestine, stomach \\
\hline \multicolumn{9}{|l|}{ Acanthocephala } \\
\hline Neoechinorbynchus curemai & 20.13 & $0.72 \pm 2.27$ & $1-15$ & Sa & 7.148 & $28.724^{*}$ & 0.058 & Intestine, pyloric cecae \\
\hline Quadrigyrus sp. & 3.35 & $0.05 \pm 0.29$ & $1-3$ & Sa & - & - & - & Intestine, stomach, pyloric cecae \\
\hline \multicolumn{9}{|l|}{ Copepoda } \\
\hline Gamidactylus jaraquensis & 15.43 & $0.58 \pm 1.92$ & $1-12$ & Sa & 5.869 & $24.510^{*}$ & 0.066 & Nasal cavity \\
\hline Gamispatulus sp. & 15.43 & $0.37 \pm 1.14$ & $1-9$ & Sa & 3.464 & $14.895^{*}$ & 0.043 & Nasal cavity \\
\hline Amplexibranchius sp. & 16.10 & $0.78 \pm 4.38$ & $1-48$ & Sa & 25.578 & $69.836^{*}$ & 0.227 & Gills \\
\hline Ergasilus sp. & 15.43 & $0.41 \pm 1.52$ & $1-14$ & Sa & 5.678 & $23.820^{*}$ & 0.078 & Gills \\
\hline \multicolumn{9}{|l|}{ Branchiura } \\
\hline Dolops sp. & 2.68 & $0.03 \pm 0.20$ & $1-2$ & $\mathrm{Sa}$ & - & - & - & Skin, Gills \\
\hline Hirudinea & 2.01 & $0.02 \pm 0.14$ & 1 & $\mathrm{Sa}$ & - & - & - & Skin \\
\hline
\end{tabular}

* Significant values

Table I. - Prevalence values (P\%), Mean abundance (MA), Amplitude of intensity (AI), Classification according to the importance for the community (Hanski, 1982; Bush \& Holmes, 1986) (Central (Ce), Secondary (Se) and Satellite species (Sa)), Dispersion index values (DI), the statistic $d$, the Green index of aggregation (GI) and the site of infection/infestation of the parasite fauna of Prochilodus lineatus, captured on the upper Paraná River floodplain from February 2000 to June 2001.

lengths per age class between parasitized and unparasitized fish.

Three-year old fish were the most intensely parasitized by the copepod Amplexibranchius sp. In the hosts of intermediate age classes (3, 4 and 5-years old), the monogenean $K$. boegeri was the most frequent. Seven-year old fish had the highest numbers of the digenean S. magnorchis. These differences were observed using the KruskallWallis test; but according to the Bonferroni correction, the abundance values are significantly different.

\section{SEX}

Of the total fish sample, 77 were females $(51.7 \%), 70$ were males ( $47 \%$ ) and the sex of two fish could not be determined (1.3\%). Among these fish, 68 females
(45.61\%), 53 males (35.6\%) and one with undetermined sex $(0.7 \%)$ were parasitized by one or more species of parasite. The Log Likelihood $\mathrm{G}$ test showed significant difference $(G=0.422 ; p=0.040)$ between the prevalence of the monogenean Tereancistrum curimba in male and female hosts, and females harboring more parasites. No significant differences were noted among abundance values based on host sex.

\section{DISCUSSION}

The results obtained in this study show the predominance of endoparasites in the metazoan parasite community of Prochilodus lineatus. The 
predominance of endoparasites, according to Pearson (1968), Williams \& Jones (1994), Cannon (1977), Kuperman (1973) and Luque et al. (1996a), is related to host feeding habits. P. lineatus, classified as iliophagous, feeds preferentially on detritus and sediment, which includes many invertebrates (mainly copepods and ostracods) (Hahn et al., 1997). Copepods and ostracods can be intermediate hosts for endoparasites, explaining the predominance in $P$. lineatus.

The presence of only one secondary species ( $R$. pseudocapsaloideum) and no central ones indicates that the parasite community is not dominated by any one species. The feeding habit can explain this. Despite having several invertebrates in this food item, a specific species does not exist. Thus, infection by several species of parasites is possible. However, parasite diversity decreased and did not present significant correlation with host size.

The overdispersed distribution pattern of the parasites of $P$. lineatus is in accordance with the typical distribution pattern found in fish parasites and can be explained by the differences between the host populations (Luque et al., 1996a). Niche heterogeneity, unpredictable recruitment or the aggregated utilization of fragmented resources favor species coexistence (Morand et al., 1999).

The occurrence of two associations between parasite species and the absence of negative associations (potential competition) can be explained by the low levels of parasitism and the absence of dominant species (centrals). In the case of $P$. lineatus, the species was positively associated with the copepod Ergasilus sp., the monogenean T. curimba and the digeneans Saccocoelioides magnorchis and S. nanii, found in the gills and intestine, respectively. These species find available spaces, and do not interact.

The length of the host, considered an expression of its age, is one of the most important factors in parasite infrapopulation variation. The monogeneans T. curimba and $K$. boegeri, and the digeneans $S$. magnorchis and S. nanii presented positive correlations - increasing parasitism abundance with the increase in fish length. According to Rohde (1993), this pattern may be due to the cumulative effect that occurs in long-life parasite species. This process is more common in ectoparasites in which the transmission is direct. In addition, fish that present a larger gill cavity and body surface can lodge more parasites (Lo et al., 1998). However, diverse studies observe the same process for endoparasites. This occurs due to changes in the behavior and physiology of the host during its ontogenetic development, as well as in its diet through an increase in the volume consumed and its composition (Luque et al., 1996b; Takemoto \& Pavanelli, 2000; Machado et al., 2000).

Influence of host age on parasite abundance is applied only to long-life parasites (Lo et al., 1998). The life cycle of these parasites is unknown in this region; however, it is known that curimba can live more than seven years (Castagnolli, 1971; Carozza \& Cordiviolade-Yuan, 1991). Studies carried out on the floodplain indicate that the species may have a higher life expectancy than observed by other authors (Lizama, 2000). Nascimento \& Iriarte (1989), Buchmann (1989) and Machado et al. (1994) also showed that the level of parasitism is related to host size, which increases over its ontogeny. The same result was obtained for some endoparasites from the upper Paraná River floodplain (Machado et al., 2000; Takemoto \& Pavanelli, 2000; Guidelli et al., 2003).

Until approximately 1.5 to two years of age, juveniles of $P$. lineatus live in lagoons, sites that serve as nurseries and feeding areas for the young population (Vazzoler et al., 1997). The phase of transition and adaptation to a new environment after leaving the lagoons make the fish more vulnerable to parasitism.

The three-year old age class prevailed among the more parasitized classes. The smallest standard length of this class is $23.7 \mathrm{~cm}$ for females. This shows that a higher degree of parasitism occurs when the hosts become adults. The prevalence of parasitism in the lower age classes was not significant. Age class preference has been described by diverse authors.

Winch (1983) studied parasites of Atrispinum labracis in Dicentrarchus labrax and observed that the fish were only infected after three years of age. The same result was obtained by Odening \& Bockhardt (1976) for Azygia lucii in Esox lucius. In P. lineatus, significant differences in weight and growth rates for classes more than three years old were also verified. The highest intensity values in the three-year old age class may be related to reproductive and/or alimentary migrations of this species. Therefore, the study of age, as well as length, has become an important tool to understand the relationships between parasites and their hosts.

Lawrence (1970), Muzzall (1980) and Conneely \& McCarthy (1986) observed that in addition to age, host sex and flood period also influenced parasite abundance. The action of these factors on the parasite fauna is considerable, mainly for those that have several organisms as intermediate hosts.

Some biotic factors are important in the host-parasite relationship. Host sex is one of them. Differences between the sexes and changes in the infestation of ectoparasites, for example, are probably related to seasonal changes in the composition of the tegument (Pickering, 1977). Endoparasites can infect the two sexes in different ways because some species of fish present different feeding habitats (Rohde, 1993).

In the present study, no influences of host sex on parasitism levels were observed. Only the monogenean T. curimba presented significant differences regarding 
host sex, with the female host being more parasitized. This shows few behavioral and physiological differences between the male and female hosts, considering that the main characteristic of $P$. lineatus is feeding and reproduction migrations.

\section{ACKNOWLEDGEMENTS}

W e would like to thank Nupélia (Center for Research in Limnology, Ichthyology and Aquaculture, Universidade Estadual de MaringáUEM) for the use of its facilities in carrying out this research and the Postgraduate Course in the Ecology of Continental Aquatic Environments (UEM) for its support during every stage of this work. We also thank Dr. José L. Luque (Universidade Federal Rural do Rio de Janeiro-UFRRJ) for help with the critical reading of the manuscript and Dr. David Hoeinghaus (Texas A \& M University) for English corrections and suggestions on the manuscript. RMT and GCP were supported by a research fellowship from CNPq (Conselho Nacional de Desenvolvimento Científico e Tecnológico).

\section{REFERENCES}

Agostinho A.A., Júlio Jr. H.F., Gomes L.C., Bini L.M. \& AgosTINHO C.S. Composição, abundância e distribuição espaçotemporal da ictiofauna, $I n$ : A planície de inundação do alto rio Paraná: aspectos físicos, biológicos e socioeconômicos. Vazzoler A.E.A. de M., Agostinho A.A. \& Hahn N.S. (eds), EDUEM, Maringá, 1997, 179-208.

BuCKMANN K. Relationship between host size of Anguilla anguilla and the infection level of the monogeneans Pseudodactylogyrus spp. Journal of Fish Biology, 1989, 35, 599-661.

Bush A.O., Aho J.M. \& Kennedy C.R. Ecological versus phylogenetics determinants of helminth parasite community richness. Evolutionary Ecology, 1990, 4, 1-20.

Bush A.O. \& Holmes J.C. Intestinal helminths of lesser scaup ducks: an interactive community. Canadian Journal of Zoology, 1986, 64, 142-152.

Bush A.O., Lafferty K.D., Lotz J.M. \& Shostak A.W. Parasitology meets ecology on its own terms: Margolis et al. revisited. Journal of Parasitology, 1997, 83, 575-583.

CANNON L.R.G. Some ecological relationships of larvas ascaridoids from south-eastern Queensland marine fishes. International Journal for Parasitology, 1977, 7, 227-232.

Carozza C. \& Cordiviola-DE-Yuan E. Estudios ictiológicos en la Laguna la Cuarentena (Isla Carabajal), Rio Paraná, Argentina: Edad y crecimiento del "sabalo" Prochilodus lineatus (Val.), periodo 1984-1985 (Pisces, Curimatidae). Revue D'Hydrobiologie Tropicale, 1991, 24, 119-129.

Castagnolu N. Idade e crescimento de três espécies da família Characidae do rio Mogi Guassu. Revista Brasileira de Biologia, 1971, 31, 519-524.
CONNEELY J.J. \& MCCARTHY T.K. Ecological factors influencing the composition of the parasite fauna of the European eel, Anguilla anguilla (L.), in Ireland. Journal of Fish Biology, 1986, 28, 207-219.

Domingues M.V. \& Boeger W.A. Neotropical Monogenoidea. 40. Protorbinoxenus prochilodi gen. n., sp. n. (Monogenoidea: Ancyrocephalinae), parasite of Prochilodus lineatus (Characiformes: Prochilodontidae) from South Brazil. Folia Parasitológica, 2002, 49, 35-38.

Esch G.W., Shostak A.W., Marcogliese D.J. \& Goater T.M. Patterns and processes in helminth parasite communities: an overview. In: Parasite communities: patterns and processes. Esch G.W, Bush A. \& Aho J. (eds), Chapman and Hall, New York, 1990, 1-20.

Eiras J.C., Takemoto R.M. \& Pavanelli G.C. Métodos de estudio y técnicas laboratoriales en parasitología de peces. Editorial Acribia, Zaragoza, 2000, 133 p.

Fugi R., Hahn N.S. \& Agostinho A.A. Feeding styles of five species of bottom-feeding fishes of the high Paraná River. Environmental Biology of Fishes, 1996, 46, 297-307.

Guidelli G.M., Isaac A., Takemoto R.M. \& Pavanelli G.C. Endoparasite Infracommunities of Hemisorubim platyrhynchus (Valenciennes, 1840) (Pisces: Pimelodidae) of the Baía River, Upper Paraná River Floodplain, Brazil: specific composition and Ecological Aspects. Brazilian Journal of Biology, 2003, 63, 261-268.

Hahn N.S., Andrian I.F., Fugi R. \& Almeida V.L. Ecologia Trófica. In: A planície de inundação do alto rio Paraná: aspectos físicos, biológicos e socioeconômicos. Vazzoler A.E.A. de M., Agostinho A.A. \& Hahn N.S. (eds), EDUEM, Maringá, 1997, 209-228.

Hanski J. Dynamics of regional distribution: the core and satellite species hypothesis. Oikos, 1982, 38, 210-221.

KUPERMAN B.I. Infection of young perch by tapeworm Triaenophorus nodulosus. Verhandlungen Der International en Vereiningung für Theoretische und Angewandte Limnologie, 1973, 18, 1697-1704.

LAWRENCE J.L. Effects of season, host age and sex on endohelminths of Catostomi commersoni. Journal of Parasitology, 1970, 56, 567-571.

LizAMA M. DE LOS A.P. Estimativa dos parâmetros de crescimento, recrutamento e mortalidade de Prochilodus lineatus da planície de inundação do alto Rio Paraná, Brasil. Boletim do Instituto de Pesca, 2000, 26, 121-128.

Lizama M. DE los A.P., Takemoto R.M. \& Pavanelli G.C. New species of Tereancistrum Kritsky, Thatcher \& Kayton, 1980 (Monogenea: Dactylogyridae: Ancyrocephalinae) from the gills of Prochilodus lineatus (Osteichthyes: Prochilodontidae) from the upper Paraná River floodplain, Brazil. Systematic Parasitology, 2004, 57, 45-49.

Lo C.M., Morand S. \& Galzin R. Parasite diversity/host age and size relationship in three coral-reef fishes from French Polynesia. International Journal for Parasitology, 1998, 28, 1695-1708.

LudWIG J.A. \& ReYNOLdS J.F. Statistical Ecology: a primer on methods and computing. Wiley-Interscience Publications, New York, 1988, 337 p.

Luque J.L., Amato J.F.R. \& Tакемото R.M. Comparative analysis of the Communities of metazoan parasites of Ortho- 
pristis ruber and Haemulon steindachneri (Osteichthyes: Haemulidae) from the southeastern Brazilian littoral: I. Structure and influence of the size and sex of hosts. Revista Brasileira de Biologia, 1996a, 56, 279-292.

Luque J.L., Amato J.F.R. \& TAKemoto R.M. Comparative analysis of the communities of metazoan parasites of Orthopristis ruber and Haemulon steindachneri (Osteichthyes: Haemulidae) from the southeastern Brazilian littoral: II. Diversity, interespecific associations, and distribution of gastrointestinal parasites. Revista Brasileira de Biologia, 1996b, 56, 293-302.

Machado M.H., Pavanelli G.C. \& Takemoto R.M. Influence of host's sex and size on endoparasitic infrapopulations of Pseudoplatystoma corruscans and Schizodon borelli (Osteichthyes) of the high Paraná river, Brazil. Revista Brasileira de Parasitologia Veterinária, 1994, 3, 143-148.

Machado P.M., Almeida S.C., Pavanelli G.C. \& Takemoto R.M. Ecological aspects of Endohelminths paraziting Cichla monoculus Spix, 1831 (Perciformes: Cichlidae) in the Paraná river near Porto Rico, State of Paraná, Brazil. Comparative Parasitology, 2000, 6, 210-217.

Martins M.L., Moraes F.R. De, Fujimoto R.Y., Onaka E.M. \& Quintana C.I.F. Prevalence and histopatology of Neoechinorbynchus curemai Noronha, 1973 (Acanthocephala: Neoechinorhynchidae) in Prochilodus lineatus Valenciennes, 1836 from Volta Grande reservoir, MG, Brazil. Brazilian Journal of Biology, 2001, 61, 517-522.

Morand S., Poulin R., Rhode K. \& Hayward C. Aggregation and species coexistence of ectoparasites of marine fishes. International Journal for Parasitology, 1999, 29, 663-672.

Moravec F. Nematodes of freshwater fishes of the Neotropical region. Academia Praha, Czech Republic, 1998, 464 p.

Muzzall P.M. Seasonal distribution and ecology of three Caryophyllaeid cestode species infecting white suckers in SE New Hampshire. Journal of Parasitology, 1980, 66, 542550 .

NASCIMENTO M.J. \& IRIARTE J.L. Las infracomunidades de parásitos metazoos del chancharro Helicolenus lengerichi Norman, 1937 (Pisces, Scorpaenidae): un ensamble no interactivo de especies. Revista Chilena de Historia Natural, 1989, 62, 217-227.

PEARSON J.C. Observations on the morphology and life-cycle of Paucivitellosus fragilis Coil, Reid and Kuntz, 1965 (Trematoda: Bivesiculidae). Parasitology, 1968, 58, 769-788.

PiCKERING A.D. Seasonal changes in the epidermis of the brown trout Salmo trutta (L.). Journal of Fish Biology, 1977, 10, 505-512.

Ranzani-Paiva M.J.T., Silva-Souza A.T., Pavanelli G.C. \& Takeмото R.M. Hematological characteristics and relative condition factor $(\mathrm{Kn})$ associated with parasitism in Schizodon borelli (Osteichthyes, Anostomidae) and Prochilodus lineatus (Osteichthyes, Prochilodontidae) from Paraná River, Porto Rico region, Paraná, Brazil. Acta Scientiarum, 2000, 22, 515-521.

RoHDE K. Ecology of marine parasites. An introduction to marine parasitology. ( $2^{\text {nd }}$ ed.). CAB International, United Kingdom, 1993, 297 p.

Takemoto R.M., Lizama M. DE los A.P. \& Pavanelli G.C. A new species of Kritskyia (Dactylogyridae, Ancyrocephalinae) parasite of urinary bladder of Prochilodus lineatus (Prochilodontidae, Characiformes) from the floodplain of the high Paraná river, Brazil. Memórias do Instituto Oswaldo Cruz, 2002, 97, 313-315.

Takemoto R.M. \& Pavanelli G.C. Aspects of the ecology of Proteocephalid cestodes parasites of Sorubim lima (Pimelodidae) of the Upper Paraná river, Brazil: Structure and influence of host's size and sex. Revista Brasileira de Biologia, 2000, 60, 577-584.

Terraes J.C., Bechara J.A., Roux J.P., Flores Quintana C., Domitrovic H. \& SÁnchez H.A.E. Ciclos reproductivos del sábalo (Prochilodus lineatus) y de sardina de río (Hemiodus orthonops) (Pisces, Characiformes) en el río Paraná águas debajo de la represa de Yacyretá, Argentina. Revista de Ictiologia, 1999, 7, 91-104.

Thatcher V.E. Quatro espécies novas da família Haploporidae (Trematoda: Digenea) de peixes de água doce da Colômbia, com uma revisão do gênero Saccocoelioides Szidat, 1954. Acta Amazônica, 1978, 8, 477-487.

Thatcher V.E. Paramphistomidae (Trematoda: Digenea) de peixes de água doce: dois novos gêneros da Colômbia e uma redescrição de Dadaytrema oxycephala (Diesing, 1836) Travassos, 1934, da Amazônia. Acta Amazônica, 1979, 9, 203-208.

Thatcher V.E. Amazon fish parasites. Amazoniana, 1991, 11, 263-571.

Thatcher V.E. Trematódeos Neotropicais. INPA, Manaus, 1993, $553 \mathrm{p}$.

Thatcher V.E. \& Varella A.B. Duas novas espécies de Megacoelium Szidat, 1954 Trematoda: Haploporidae), parasitas estomacais de peixes da Amazônia Brasileira, com uma redefinição do gênero. Acta Amazônica, 1981, 11, 285-289.

Thatcher V.E. \& Boeger W. The parasitic crustaceans of fishes from the Brazilian Amazon. 13. Gamidactylus jaraquensis gen. et sp. nov. (Copepoda: Poecilostomatoida: Vaigamidae) from the nasal fossae of Semaprochilodus insignis (Schomburgk). Amazoniana, 1984a, 8, 421-426.

Thatcher V.E. \& Boeger W. The parasitic crustaceans of fishes from the Brazilian Amazon. 15. Gamispatulus schizodontis gen. et sp. nov. (Copepoda: Poecilostomatoida: Vaigamidae) from the nasal fossae of Schizodontidae fasciatus Agassiz. Amazoniana, 1984b, 9, 119-126.

Williams H.M. \& Jones A. Parasitic worms of fish. Taylor \& Francis, London, 1994, 563 p.

WINCH J. The biology of Atrispinum labracis n. comb. (Monogenea) on the gills of the bass, Dicentrarchus labrax. Journal of the Marine Biological Association of the United Kingdom, 1983, 63, 915-927.

Vazzoler A.E.A. DE M., Suzuki H.I., Marques E.E. \& Lizama M. DE LOS A.P. Primeira maturação gonadal, períodos e áreas de reprodução. In: A planície de inundação do alto rio Paraná: aspectos físicos, biológicos e socioeconômicos. Vazzoler A.E.A. de M., Agostinho A.A. \& Hahn N.S. (eds). EDUEM, Maringá, 1997, 249-265.

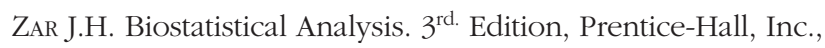
Upper Saddle River, New Jersey, USA, 1996, 662 p.

Reçu le 8 avril 2004 Accepté le 4 août 2005 